Vol. 1 No. 2, Juni 2021, hlm. 127 - 134

DOI: https://doi.org/10.33330/jutsi.v2i1.1151

Available online at http://jurnal.stmikroyal.ac.id/index.php/jutsi

\title{
PENILAIAN KINERJA SATUAN TUGAS TERBAIK MENGGUNAKAN METODE MFEP PADA KANTOR BPBD KOTA TANJUNGBALAI
}

\author{
Zainuddin $^{1}$, Nofriadi ${ }^{2}$, Nasrun Marpaung ${ }^{3}$ \\ ${ }^{1}$ Mahasiswa Prodi Sistem Informasi, STMIK Royal \\ ${ }^{2}$ Prodi Sistem Komputer, STMIK Royal \\ ${ }^{3}$ Prodi Sistem Informasi, STMIK Royal \\ *email: nofriadi.royal85@yahoo.com
}

\begin{abstract}
Duty unit office Regional Disaster Management Agency Tanjungbalai City have a big task includes looking for, helping, and save human worried lost or face danger in natural disasters. In carrying out this great task There are also duty unit less active, professional, and lack of sense of responsibility in work So that it affects other co-workers. This is due to the placement of the task force not in accordance with the skills he has. Therefore, the purpose of this research is to assist the Technical Implementation Officer of Activities in determine performance duty unit appraisal best. System development method using Multi Factor Evaluation Process (MFEP). The resulting Decision Support System can make it easier Activity Technical Implementing Officer in do an assessment duty unit performance at work environment office Regional Disaster Management Agency Tanjungbalai City.
\end{abstract}

Keywords: SPK;Performance assessment; PPTK; MFEP

\begin{abstract}
Abstrak: Satuan Tugas (SATGAS) Kantor Badan Penanggulangan Bencana Daerah Kota Tanjungbalai mempunyai tugas besar meliputi mencari, menolong, dan menyelamatkan jiwa manusia yang dikhawatirkan hilang atau menghadapi bahaya dalam musibah bencana alam. Dalam menjalankan tugas besar tersebut ada juga Satuan Tugas (SATGAS) yang kurang aktif, propesional, dan kurang rasa tanggungjawab dalam bekerja, sehingga mempengaruhi rekan kerja lainnya dalam melaksanakan tugasnya. Hal ini di sebabkan penempatan satgas tidak sesuai dengan skill yang dimilikinya. Oleh karana itu tujuan dari penelitian ini adalah untuk membantu Pejabat Pelaksana Teknis Kegiatan (PPTK) dalam menantukan penilaian kinerja Satuan Tugas (SATGAS) terbaik. Metode pengembangan sistem menggunakan Multi Factor Evaluation Process (MFEP). Sistem Pendukung Keputusan yang dihasilkan dapat mempermudah Pejabat Pelaksana Teknis Kegiatan (PPTK) dalam melakukan penilaian kinerja satagas di lingkungan kerja Kantor Badan Penanggulangan Bencana Daerah Kota Tanjungbalai
\end{abstract}

Kata kunci: SPK; Penilaian Kinerja; PPTK; MFEP

\section{PENDAHULUAN}

Satuan Tugas (SATGAS) merupakan sebuah unit atau formasi yang dibentuk untuk mengerjakan tugas tertentu, sebagai komponen dalam bidang kebencanaan. seorang Satuan Tugas (SATGAS) juga harus memiliki kemampuan dalam 
Vol. 1 No. 2, Juni 2021, hlm. $127-134$

DOI: https://doi.org/10.33330/jutsi.v2i1.1151

Available online at http://jurnal.stmikroyal.ac.id/index.php/jutsi

melaksanakan pencarian dan pertolongan dalam usaha dan kegiatan yang meliputi mencari, menolong, dan menyelamatkan jiwa manusia yang terkena musibah bencana alam. Pada Kantor Badan Penanggulangan Bencana Daerah Kota Tanjungbalai memiliki 22 orang ASN dan 37 orang Satuan Tugas (SATGAS) yang terdiri dari lakilaki 28 orang dan perempuan 9 orang [1][2].

Dalam menjalankan tugas besar tersebut ada juga Satuan Tugas (SATGAS) yang kurang aktif, propesional, dan kurang rasa tanggungjawab dalam bekerja, sehingga mempengaruhi rekan kerja lainnya dalam melaksanakan tugasnya. maka dari pada itu Pejabat Pelaksana Teknis Kegiatan (PPTK) mengambil sikap tegas kepada Satuan Tugas (SATGAS) yang tidak mengikuti peraturan dan prosedur dalam bertugas berupa Sangsi berupa teguran surat, lisan, hingga pemotongan gaji [3][4].

Maka dari pada itu Pejabat Pelaksana Teknis Kegiatan (PPTK) membuat program penghargaan kepada Satuan Tugas (SATGAS) yang bertanggungjawab dalam menjalankan tugas sesuai peraturan dan prosedur berupa tambahan penghasilan dari hasil pemotongan gaji Satuan Tugas (SATGAS) yang kurang aktif dalam menjalankan tugas [5][6][7].

Namun Pejabat Pelaksana Teknis Kegiatan (PPTK) masih memiliki masalah dan bingung dalam mengambil keputusan dalam penilaian kinerja Satuan Tugas (SATGAS) terbaik yang sampai sekarang ini masih menggunakan metode lama dan dilakukannya secara manual dengan menggunakan buku catatan dan kertas HVS, yang bisa saja hilang dan rusak menghabiskan banyak waktu dalam melakukan penilaian kinerja. data yang kurang lengkap mengakibatkan kurang tepatnya sasaran dalam penilaian dan menimbulkan berbagai kontra terhadap sesama Satuan Tugas (SATGAS) yang merasa tidak puas dalam penilaian yang selama ini dibuat.

\section{METODE}

Dalam melakukan penelitian penilaian kinerja satgas di BPBD kota tanjung balai, dilakukan langkah-langkah sebagai berikut: (1) Memilih faktor dan nilai bobot faktor kemudian nilai pembobotan harus sama dengan $1(\Sigma$ pembobotan $=1)$ yaitu FactorWeight., (2) Menginputkan nilai terhadap setiap faktor yang akan berpengaruh kepada pengambilan keputusan. Data dan nilai yang diinputkan dalam proses pengambilan keputusan adalah data dan nilai yang objektif., (3) Proses perhitungan Weight Evaluation adalah proses perhitungan nilai bobot antara Factor Weight dan Factor Evaluation dengan menjumlahkan seluruh hasil Weight Evaluations untuk mendapatkan total hasil evaluasi. Penggunaan Metode Multifactor Evaluation Process (MFEP) dapat disimpulkan sebagai berikut:

Perhitungan nilai bobot evaluasi ditunjukkan dalam persamaan (1):

$$
E F=\frac{\sum x}{\sum x \max }
$$

Keterangan:

$$
\begin{array}{ll}
E F & : \text { Evaluasi Faktor } \\
X & : \text { Nilai Subkriteria } \\
X \text { max } & : \text { Nilai X Max }
\end{array}
$$


Vol. 1 No. 2, Juni 2021, hlm. 127 - 134

DOI: https://doi.org/10.33330/jutsi.v2i1.1151

Available online at http://jurnal.stmikroyal.ac.id/index.php/jutsi

Perhitungan nilai bobot evaluasi ditunjukkan dalam persamaan (2):

$W E=F W \times E$

Keterangan:

$W E$ : Nilai Bobot Evaluasi

$F W$ : Nilai Bobot Faktor

E : Nilai Evaluasi Faktor

Perhitungan nilai total evaluasi ditujukkan dalam persamaan (3):

$$
\begin{gathered}
\sum_{i=1}^{n} W E_{i}=W E_{1}+W E_{2}+\ldots .+W E_{n} \\
\text { Keterangan: } \\
\sum_{i=1}^{n} W E_{i} \\
W E_{i}: \text { Total Nilai Bobot Evaluasi } \\
\text { : Nilai Bobot Evaluasi ke- } i
\end{gathered}
$$

\section{HASIL DAN PEMBAHASAN}

Berdasarkan permasalahan yang ada, Penilaian satuan tugas (SATGAS) terbaik akan dibuat dengan sistem yang lebih baik. Kepala Pelaksana BPBD Kota Tanjungbalai dan PPTK Satgas dapat menilai satuan tugas (SATGAS) terbaik dengan menggunakan sistem pendukung keputusan yang berbasis komputer berdasarkan Kriteria, Bobot kriteria dan nilai evaluasi yang telah ditetapkan. Dengan adanya Penilaian satuan tugas (SATGAS) terbaik yang dibuat maka akan meminimalisir terjadinya kesalahan dalam Penilaian satuan tugas (SATGAS) terbaik, sehingga nantinya bisa menjadi motivasi dan pendorong untuk kinerja satuan tugas (SATGAS) yang lebih baik lagi.

Perhitungan yang dilakukan dengan menggunakan metode Multi Factor Evaluation Process (MFEP) adalah dengan menggunakan kriteria-kriteria Penilaian kinerja Satuan Tugas (SATGAS) terbaik pada Kantor Badan Penanggulangan Bencana Daerah Kota Tanjungbalai. Pada penelitian ini telah menentukan standart dalam menentukan penilaian kinerja Satuan Tugas (SATGAS) terbaik pada Kantor Badan Penanggulangan Bencana Daerah Kota Tanjungbalai untuk 37 orang Satuan Tugas (SATGAS) dapat dilihat pada tabel 1.

Tabel 1. Standart Penilaian kinerja Satuan Tugas (SATGAS) Terbaik

\begin{tabular}{|c|l|l|}
\hline No & \multicolumn{1}{|c|}{ Hasil Akhir } & \multicolumn{1}{c|}{ Keputusan } \\
\hline 1 & 86 s/d 100 & Sangat Baik \\
\hline 2 & 80 s/d 85 & Baik \\
\hline 3 & 65 s/d 79 & Cukup \\
\hline 4 & $<65$ & Kurang \\
\hline
\end{tabular}

Pada penelitian ini akan digunakan data 37 orang Satuan Tugas (SATGAS) dalam menentukan menentukan faktor dan bobot faktor dimana total pembobotan harus sama dengan 1, yaitu factor weight data kriteria untuk penilaian kinerja Satuan Tugas (SATGAS) terbaik pada Kantor Badan Penanggulangan Bencana Daerah Kota Tanjungbalai dapat dilihat pada tabel 2. 
Vol. 1 No. 2, Juni 2021, hlm. $127-134$

DOI: https://doi.org/10.33330/jutsi.v2i1.1151

Available online at http://jurnal.stmikroyal.ac.id/index.php/jutsi

Tabel 2. Data Kriteria

\begin{tabular}{|c|l|l|c|}
\hline No & Kode Kriteria & Nama Kriteria & $\begin{array}{c}\text { Presentase Bobot } \\
\text { Komponen }\end{array}$ \\
\hline 1 & K01 & Aspek Disiplin & 30 \\
\hline 2 & K02 & Orientasi Pelayanan & 10 \\
\hline 3 & K03 & Kepemimpinan & 10 \\
\hline 4 & K04 & Kerja Sama & 20 \\
\hline 5 & K05 & Integritas & 10 \\
\hline 6 & K06 & Komitmen & 20 \\
\hline
\end{tabular}

Pada penelitian ini, digunakan data 37 orang Satuan Tugas (SATGAS) dalam Mengisikan nilai untuk setiap faktor yang mempengaruhi dalam pengambilan keputusan dari rata-rata yang akan diproses, nilai yang dimasukan dalam proses pengambilan keputusan merupakan nilai objektif yaitu nilai 10-100 yang sudah memiliki aturan paten

Kriteria Aspek Disiplin merupakan nilai sub kriteria yang diambil dari rekapan manual absensi Satuan Tugas (SATGAS) untuk menentukan nilai bobot dari aspek Disiplin dapat dilihat pada tabel 3.

Tabel 3. Kriteria Aspek Disiplin

\begin{tabular}{|c|c|c|}
\hline Kehadiran & Keterangan & Nilai Bobot \\
\hline $0-9$ Hari & Tidak Disiplin & 20 \\
\hline $10-15$ Hari & Kurang Disiplin & 40 \\
\hline $16-20$ Hari & Cukup Disiplin & 60 \\
\hline $21-25$ Hari & Disiplin & 80 \\
\hline $26-30$ Hari & Sangat Disiplin & 100 \\
\hline
\end{tabular}

Kriteria Orientasi Pelayanan merupakan nilai sub kriteria yang diambil dari rekapan manual kegiatan Satuan Tugas (SATGAS) untuk menentukan nilai bobot dari orientasi pelayanan dapat dilihat pada tabel 4.

Tabel 4. Kriteria Orientasi Pelayanan

\begin{tabular}{|c|c|c|}
\hline Kegiatan & Keterangan & Nilai Bobot \\
\hline $0-4$ Kali & Tidak Baik & 20 \\
\hline $5-8$ Kali & Kurang Baik & 40 \\
\hline $9-12$ Kali & Cukup Baik & 60 \\
\hline $13-16$ Kali & Baik & 80 \\
\hline $17-20$ Kali & Sangat Baik & 100 \\
\hline
\end{tabular}

Kriteria kepemimpinan merupakan nilai sub kriteria yang diambil dari rekapan manual kegiatan Satuan Tugas (SATGAS) untuk menentukan nilai bobot dari kepemimpinan dapat dilihat pada tabel 5. 
Vol. 1 No. 2, Juni 2021, hlm. $127-134$

DOI: https://doi.org/10.33330/jutsi.v2i1.1151

Available online at http://jurnal.stmikroyal.ac.id/index.php/jutsi

Tabel 5. Kriteria Kepemimpinan

\begin{tabular}{|c|c|c|}
\hline Kegiatan & Keterangan & Nilai Bobot \\
\hline $0-2$ Kali & Tidak Berwibawa & 20 \\
\hline $3-4$ Kali & Kurang Berwibawa & 40 \\
\hline $5-6$ Kali & Cukup Berwibawa & 60 \\
\hline $7-8$ Kali & Berwibawa & 80 \\
\hline $9-10$ Kali & Sangat Berwibawa & 100 \\
\hline
\end{tabular}

Kriteria Kerjasama merupakan nilai sub kriteria yang diambil dari rekapan manual kegiatan Satuan Tugas (SATGAS) untuk menentukan nilai bobot dari kerjasama dapat dilihat pada tabel 6 .

Tabel 6. Kriteria Kerjasama

\begin{tabular}{|c|c|c|}
\hline Kegiatan & Keterangan & Nilai Bobot \\
\hline $0-4$ Kali & Tidak Peduli & 20 \\
\hline $5-8$ Kali & Kurang Peduli & 40 \\
\hline $9-12$ Kali & Cukup Peduli & 60 \\
\hline $13-16$ Kali & Peduli & 80 \\
\hline $17-20$ Kali & Sangat Peduli & 100 \\
\hline
\end{tabular}

Kriteria Integritas merupakan nilai sub kriteria yang diambil dari rekapan manual kegiatan Satuan Tugas (SATGAS) untuk menentukan nilai bobot dari Integritas dapat dilihat pada tabel 7.

Tabel 7. Kriteria Integritas

\begin{tabular}{|c|c|c|}
\hline Kegiatan & Keterangan & Nilai Bobot \\
\hline $0-2$ Kali & Tidak Loyal & 20 \\
\hline $3-4$ Kali & Kurang Loyal & 40 \\
\hline $5-6$ Kali & Cukup Loyal & 60 \\
\hline $7-8$ Kali & Loyal & 80 \\
\hline $9-10$ Kali & Sangat Loyal & 100 \\
\hline
\end{tabular}

Kriteria Komitmen merupakan nilai sub kriteria yang diambil dari rekapan manual kegiatan Satuan Tugas (SATGAS) untuk menentukan nilai bobot dari Komitmen dapat dilihat pada tabel 8.

Tabel 8. Kriteria Komitmen

\begin{tabular}{|c|c|c|}
\hline Kegiatan & Keterangan & $\begin{array}{c}\text { Nilai } \\
\text { Bobot }\end{array}$ \\
\hline $0-2$ Kali & Tidak Bertanggungjawab & 20 \\
\hline $3-4$ Kali & Kurang Bertanggungjawab & 40 \\
\hline $5-6$ Kali & Cukup Bertanggungjawab & 60 \\
\hline $7-8$ Kali & Bertanggungjawab & 80 \\
\hline $9-10$ Kali & Sangat Bertanggungjawab & 100 \\
\hline
\end{tabular}


Vol. 1 No. 2, Juni 2021, hlm. $127-134$

DOI: https://doi.org/10.33330/jutsi.v2i1.1151

Available online at http://jurnal.stmikroyal.ac.id/index.php/jutsi

Setelah mengetahui data alternatif, selanjutnya pada kasus ini akan digunakan data 37 orang Satuan Tugas (SATGAS) dalam menentukan nilai evaluasi untuk penilaian kinerja Satuan Tugas (SATGAS) terbaik pada Kantor Badan Penanggulangan Bencana Daerah Kota Tanjungbalai dapat dilihat pada tabel 9.

Tabel 9. Nilai Evaluasi

\begin{tabular}{|c|c|c|c|c|c|c|c|}
\hline No & Nama Anggota & K01 & K02 & K03 & K04 & K05 & K06 \\
\hline 1 & Arief Dhermawan & 30 & 20 & 10 & 20 & 10 & 10 \\
\hline 2 & Monyca Febryana Butar -Butar, S. Kep, Ners & 18 & 4 & 8 & 16 & 10 & 6 \\
\hline 3 & Muhammad Haidir & 18 & 8 & 2 & 4 & 2 & 4 \\
\hline 4 & Muhammad Alkudri Amhas, SH & 30 & 8 & 2 & 4 & 4 & 4 \\
\hline 5 & Alfatah Rizki Salam & 24 & 16 & 6 & 12 & 6 & 8 \\
\hline 6 & Syamsuddin & 30 & 20 & 8 & 20 & 6 & 10 \\
\hline 7 & Arrina Clora Dumichen, SPd & 18 & 16 & 2 & 4 & 2 & 2 \\
\hline 8 & Muhammad Nawir Pane, Amd. Kom & 30 & 20 & 8 & 12 & 6 & 6 \\
\hline 9 & Lahmuddin Dalimunthe & 12 & 12 & 2 & 4 & 2 & 2 \\
\hline 10 & Ihsan Iskandar & 24 & 16 & 4 & 16 & 6 & 2 \\
\hline 11 & Rusdianto & 24 & 8 & 2 & 4 & 2 & 2 \\
\hline 12 & Ardiansyah Ritonga & 30 & 4 & 2 & 4 & 4 & 4 \\
\hline 13 & Dara Ulfatunnisa & 18 & 16 & 8 & 16 & 2 & 10 \\
\hline 14 & Herman, Amd. Kom & 30 & 20 & 4 & 20 & 8 & 6 \\
\hline 15 & Zainuddin, Amd. Kom & 30 & 20 & 8 & 20 & 10 & 10 \\
\hline 16 & Vivi Efira Sitompul & 12 & 4 & 6 & 4 & 2 & 2 \\
\hline 17 & Mimi Ivyka Aryani, S.Kom & 30 & 20 & 6 & 12 & 6 & 6 \\
\hline 18 & Liza Endang Muklyana Ar STR, SPd & 12 & 12 & 6 & 12 & 6 & 6 \\
\hline 19 & Risya Maulida Batu Bara, SE & 30 & 20 & 4 & 12 & 6 & 6 \\
\hline 20 & Vidi Rahman Solih Sambas & 30 & 20 & 8 & 20 & 8 & 10 \\
\hline 21 & Hari Aidil Ritonga & 18 & 8 & 6 & 12 & 10 & 10 \\
\hline 22 & Ichsan Wahyudi & 18 & 4 & 8 & 8 & 10 & 10 \\
\hline 23 & Muhammad Fadli Mangungsong & 18 & 12 & 2 & 4 & 2 & 2 \\
\hline 24 & Ari Pranata Irawan Lobo & 18 & 8 & 2 & 4 & 2 & 2 \\
\hline 25 & Hezron Simatupang & 12 & 12 & 6 & 12 & 8 & 6 \\
\hline 26 & Rahmat Hidayat Nasution & 24 & 16 & 8 & 12 & 6 & 10 \\
\hline 27 & Heriandy Panjaitan & 30 & 20 & 8 & 12 & 10 & 10 \\
\hline 28 & Monang Nainggolan & 6 & 8 & 4 & 4 & 2 & 4 \\
\hline 29 & Ahmad Sukri & 30 & 20 & 8 & 20 & 6 & 8 \\
\hline 30 & Deni Septian,ST & 30 & 20 & 6 & 16 & 6 & 6 \\
\hline 31 & Ajir Muhajir, SH & 30 & 8 & 4 & 4 & 2 & 2 \\
\hline 32 & Rini Masitoh, SE & 24 & 8 & 6 & 16 & 2 & 10 \\
\hline 33 & Solihin Wijaya Sinulingga & 24 & 8 & 4 & 4 & 4 & 2 \\
\hline 34 & Sofian Hadi & 24 & 16 & 6 & 8 & 10 & 10 \\
\hline 35 & Darma Mizwar & 18 & 4 & 2 & 4 & 2 & 2 \\
\hline 36 & Fatia Nurul Aini, SPd & 18 & 12 & 6 & 12 & 6 & 6 \\
\hline 37 & Muhammad Alfharisi, S. Sos & 30 & 20 & 8 & 16 & 6 & 6 \\
\hline
\end{tabular}

Setelah mengetahui nilai evaluasi, selanjutnya pada kasus ini akan digunakan data 37 orang Satuan Tugas (SATGAS) dalam menentukan perangkingan untuk penilaian kinerja Satuan Tugas (SATGAS) Terbaik Pada Kantor Badan Penanggulangan Bencana Daerah Kota Tanjungbalai dapat dilihat pada tabel 10. 
Vol. 1 No. 2, Juni 2021, hlm. $127-134$

DOI: https://doi.org/10.33330/jutsi.v2i1.1151

Available online at http://jurnal.stmikroyal.ac.id/index.php/jutsi

Tabel 10. Data perankingan

\begin{tabular}{|c|c|c|c|c|c|}
\hline No & Nomor Anggota & Nama Anggota & Total & Ranking & Keterangan \\
\hline 1 & 33002030056236 & Arief Dhermawan & 100 & 1 & Sangat Bagus \\
\hline 2 & 33002040229663 & Zainuddin, Amd. Kom & 98 & 2 & Sangat Bagus \\
\hline 3 & 33002040245646 & Vidi Rahman Solih Sambas & 96 & 3 & Sangat Bagus \\
\hline 4 & 33002030060926 & Syamsuddin & 94 & 4 & Sangat Bagus \\
\hline 5 & 33002040248026 & Ahmad Sukri & 92 & 5 & Sangat Bagus \\
\hline 6 & 33002040247982 & Heriandy Panjaitan & 90 & 6 & Bagus \\
\hline 7 & 33002040229638 & Herman, Amd. Kom & 88 & 7 & Bagus \\
\hline 8 & 33102040063116 & Muhammad Alfharisi, S. Sos & 86 & 8 & Bagus \\
\hline 9 & 33002040248063 & Deni Septian,ST & 84 & 9 & Bagus \\
\hline 10 & 33002030060985 & Muhammad Nawir Pane, Amd. Kom & 82 & 10 & Bagus \\
\hline 11 & 33002040245425 & Mimi Ivyka Aryani, S.Kom & 80 & 11 & Cukup Bagus \\
\hline 12 & 33002040245591 & Risya Maulida Batu Bara, SE & 78 & 12 & Cukup Bagus \\
\hline 13 & 33002040247912 & Rahmat Hidayat Nasution & 76 & 13 & Cukup Bagus \\
\hline 14 & 33002080012909 & Sofian Hadi & 74 & 14 & Cukup Bagus \\
\hline 15 & 33002030060915 & Alfatah Rizki Salam & 72 & 15 & Cukup Bagus \\
\hline 16 & 33002030069422 & Dara Ulfatunnisa & 70 & 16 & Cukup Bagus \\
\hline 17 & 33002030061103 & Ihsan Iskandar & 68 & 17 & Kurang Bagus \\
\hline 18 & 33002040248181 & Rini Masitoh, SE & 66 & 18 & Kurang Bagus \\
\hline 19 & 33002040247702 & Hari Aidil Ritonga & 64 & 19 & Kurang Bagus \\
\hline 20 & 33002030060134 & Monyca Febryana Butar -Butar, S. Kep, Ners & 62 & 20 & Kurang Bagus \\
\hline 21 & 33102030018304 & Fatia Nurul Aini, SPd & 60 & 21 & Kurang Bagus \\
\hline 22 & 33002040247820 & Ichsan Wahyudi & 58 & 22 & Kurang Bagus \\
\hline 23 & 33002040247901 & Hezron Simatupang & 56 & 23 & Kurang Bagus \\
\hline 24 & 33002040245580 & Liza Endang Muklyana Ar STR, SPd & 54 & 24 & Kurang Bagus \\
\hline 25 & 33002030060893 & Muhammad Alkudri Amhas, SH & 52 & 25 & Kurang Bagus \\
\hline 26 & 33002040248100 & Ajir Muhajir, SH & 50 & 26 & Kurang Bagus \\
\hline 27 & 33002030061125 & Ardiansyah Ritonga & 48 & 27 & Tidak Bagus \\
\hline 28 & 33002040249371 & Solihin Wijaya Sinulingga & 46 & 28 & Tidak Bagus \\
\hline 29 & 33002030060941 & Arrina Clora Dumichen, SPd & 44 & 29 & Tidak Bagus \\
\hline 30 & 33002030061114 & Rusdianto & 42 & 30 & Tidak Bagus \\
\hline 31 & 33002040247886 & Muhammad Fadli Mangungsong & 40 & 31 & Tidak Bagus \\
\hline 32 & 33002030060856 & Muhammad Haidir & 38 & 32 & Tidak Bagus \\
\hline 33 & 33002040247890 & Ari Pranata Irawan Lobo & 36 & 33 & Tidak Bagus \\
\hline 34 & 33002030061081 & Lahmuddin Dalimunthe & 34 & 34 & Tidak Bagus \\
\hline 35 & 33002090020526 & Darma Mizwar & 32 & 35 & Tidak Bagus \\
\hline 36 & 33002040242102 & Vivi Efira Sitompul & 30 & 36 & Tidak Bagus \\
\hline 37 & 33002040248015 & Monang Nainggolan & 28 & 37 & Tidak Bagus \\
\hline
\end{tabular}

\section{SIMPULAN}

Berdasarkan Hasil dari implementasi dan pengujian yang sudah dilakukan dalam perancangan Sistem Pendukung Keputusan Penilaian kinerja satgas terbaik menggunakan Metode MFEP (Multifactor Evaluation Process) maka dapat dismpulkan bahwa memberikan hasil yang lebih optimal dalam mengolah data saat melakukan penilain.Dan juga mempermudah Pejabat Pelaksana Teknis Kegiatan (PPTK) dalam melakukan penilaian kinerja satgas. Serta proses penilaian lebih cepat dan menghemat waktu dibandingkan dengan metode lama secara manual. 
Vol. 1 No. 2, Juni 2021, hlm. $127-134$

DOI: https://doi.org/10.33330/jutsi.v2i1.1151

Available online at http://jurnal.stmikroyal.ac.id/index.php/jutsi

\section{DAFTAR PUSTAKA}

[1] K. B. Banjir, "Kinerja Badan Penanggulangan Bencana Daerah (Bpbd) Kota Manado Dalam Upaya Penanggulangan Korban Bencana Banjir," J. Eksek., vol. 1, no. 1, 2018.

[2] I. Ramadhan, "Peran Badan Penanggulangan Bencana Daerah (BPBD) Kota Medan (Studi Kasus Penanggulangan Bencana Alam di Kecamatan Medan Labuhan)," vol. 6, no. 4, pp. 1775-1788, 2015, [Online]. Available: http://repository.uma.ac.id/handle/123456789/183.

[3] C.-D. I. K. Padangsambian, K. Denpasar, I. M. H. Prasetia, I. G. Ngurah, and D. Paramartha, "PARTA: Jurnal Pengabdian Kepada Masyarakat DESA ADAT DALAM RANGKA PENCEGAHAN WABAH CORONA VIRUS DISEASE 2019 Pendahuluan," vol. 1, no. 1, pp. 36-43, 2020.

[4] E. N. Handayani, "Manajemen Kinerja Satuan Tugas Penurunan Angka Mempercepat Penurunan Angka Kematian Ibu Dan Bayi Di Kota Surabaya,” pp. 1-14, 2014.

[5] R. Turaina, "Spk Dalam Pemilihan Siswa Kelas Unggul Menggunakan Metode Mfep Di Smp N 2 Solok," Edik Inform., vol. 3, no. 2, pp. 125-135, 2017, doi: 10.22202/ei.2017.v3i2.1662.

[6] M. Ikhlas, "Penerapan Metode Mfep (Multifactor Evaluation Process) Dalam Pengambilan Keputusan Pemilihan Bibit Kelapa Sawit Terbaik," J. Sains dan Teknol. J. Keilmuan dan Apl. Teknol. Ind., vol. 19, no. 1, p. 16, 2019, doi: 10.36275/stsp.v19i1.128.

[7] S.- Supiyandi, A. P. U. Siahaan, and A. Alfiandi, "Sistem Pendukung Keputusan Pemilihan Pegawai Honorer Kelurahan Babura dengan Metode MFEP," J. Media Inform. Budidarma, vol. 4, no. 3, p. 567, 2020, doi: 10.30865/mib.v4i3.2107. 